\title{
Using Translanguaging in Higher Education to Empower Students' Voices and Enable Epistemological Becoming
}

Fouad Asfour

ORCID iD: https://orcid.org/0000-0002-1087-2879

Yanela Ndabula

ORCID iD: https://orcid.org/0000-0002-8436-8827

Gamuchirai Chakona

ORCID iD: https://orcid.org/0000-0003-3784-8980

\section{Paul Mason}

ORCID iD: https://orcid.org/0000-0002-8100-792X

\author{
David O. Oluwole \\ ORCID iD: https://orcid.org/0000-0002-3018-327X
}

\begin{abstract}
This article is based on research conducted by a group of plurilingual postgraduate students from different disciplines who facilitated writing groups at the Centre for Postgraduate Studies at Rhodes University over the past two years. It is based on self-reflective writing of language biographies and aims to raise attention about, and to open up a discussion on, the impact of social and personal language practices. We approach the role of language not only as complex interrogation of academic identity, but also as sense of embodied self, an active element in the formation of geo- and body-politics of knowledge which has been highlighted in recent literature focussing on translanguaging in
\end{abstract}


education and decolonising the curricula of Higher Education. Following selfguided research, we engaged in a critical reflection on the use of home languages in education and consulted relevant literature that argues for the inclusion of translanguaging practices in Higher Education. Our research, therefore, focuses on new epistemologies afforded by a shift away from the monolingual habitus and from the concept of multilingualism towards plurilingualism and translanguaging. Our data suggests that a plurilingual approach towards teaching and learning in Higher Education can afford epistemological access to learners across faculties and disciplines in Higher Education, and we argue that the role of languages of tuition in curricula need to be strategically re-evaluated.

Keywords: Higher Education, curriculum transformation, decolonising curricula, translanguaging, plurilingualism, monolingual bias, interdisciplinary writing group, postgraduate scholars, translanguaging, writing practices, selfreflexive, language biography writing, educational practice, writing groups facilitation, social epistemological knowledge

\section{Introduction}

We have argued previously that writing groups ${ }^{1}$ are valuable spaces in which postgraduate students are able to develop the literacy practices of their disciplines (Oluwole et al. 2018; Wilmot \& McKenna 2018). ${ }^{2}$ They provide scholars with an opportunity to try out new discourse and to build confidence in fledgling research identities in collaborative groups of fellow students.

${ }^{1}$ In this article, 'writing groups' refer to the peer-led groups of students consulting and writing. These occur in different forms internationally, as outlined by Shabanza (2017), while the writing groups organised by the Rhodes Centre for Postgraduate Studies were referred to as 'Writing Circles'. ${ }^{2}$ This article is the result of a team of postgraduate writing group facilitators at the Rhodes Centre for Postgraduate Studies, made possible thanks to the generous support of and critical feedback by Prof Sioux McKenna, director of the CPGS who kept supporting the efforts of our research group, continued to engage rigorously with our data, and encouraged us and challenged us to keep going in the process of our research. 
Furthermore, these groups are free from the power differentials that so often mark supervision relationships. Given the efforts to ensure equality in these relational contexts, which encourage experimentation within the academy, we are interested in how writing groups might function as places where translanguaging can be harnessed as a 'vehicle for epistemic access' (Makalela 2015: 15). In this article, we set out as a group of writing group facilitators to reflect on our own language practices and how plurilingualism ${ }^{3}$ has shaped our own writing development and to explore translanguaging as a tool for knowledge creation and growth. Writing groups presently are extracurricular spaces that students use to critically review each other's writing practices. Our research draws from the fundamental premise of collegiality (Oluwole et al. 2018) in writing groups which we claim enables students to tackle difficult questions about the use of home languages as academic literacy skill rather than as obstacle, while acknowledging that it is a process that is experienced as difficult and challenging (Mgqwashu 2009; 2011).

In this article, we reflect critically and analyse the findings from our self-led research process of language biography writing (see Busch et al. 2006) which highlight the complex (and at times contradictory) interaction of home language and language of tuition in acquiring academic literacy skills through translanguaging, i.e. writing between languages (Guzula et al. 2016; Makalela 2015). We do this while focussing on the role that awareness of the plurilingual situation of learners can play, via writing practices, in developing epistemological depth, conceptual depth, conformity, and resistance, as well as

${ }^{3}$ In this article, we use plurilingualism as a concept that frames the situation of a South African learner in the education system, whereas translanguaging denotes the speakers' use of their languages as repertoire. This is based on the distinctions elaborated on in Garcia and Otheguy (2019) who observe that multilingualism tends to describe a social phenomenon whereas plurilingualism specifically highlights not only the awareness and competence of speakers, but also that home language, or L1, is important for the development of L2 or L3. The authors highlight raciolinguistic ideologies in Europe that require plurilingual refugees to speak and use the national language in what is considered a 'native norm'. Translanguaging, however, 'rests on the idea that the concept of the named language, and the related concepts of language purity and verbal hygiene, were constructed to support ideologies of racial, class, and gender superiority' (Garcia \& Otheguy 2019: 9). 
identity validation. Thus, we argue that peer-led translanguaging academic writing group practices need to be included as curricular activities, so as to help students to gain insight into how their writing is shaped by language ideologies and to question how these are either reproduced or questioned in their scholarly work. We claim that the process of sharing difficulties and contradictory experiences, such as the tension between the desire to conform and resistance against challenging formal requirements in writing, can lead to processes of epistemological becoming in plurilingual postgraduate students. We begin with a brief discussion of the literacies framework that underpins the use of writing groups.

\section{From Epistemological Access to Epistemological Becoming}

Knowledge is made in various ways inside and outside of the academy and across different disciplines. What counts as truth varies between Philosophy and Physics, as does what counts as suitable evidence for that truth. When students enrol in university, armed with their school leaving certificates and years of hard work, they are often confronted with what seems to be an entirely marginalising environment as they access new forms of knowledge and are expected to make sense of the world in new ways. This process is often not made explicit and they may find few opportunities to try out these new practices and get formative feedback to guide them as McKenna (2010) points out.

Despite the rhetoric that the academy is a meritocracy where anybody who puts in the hard work will be duly rewarded, research around the world shows that it is socioeconomic demographics that most strongly correlate to Higher Education success (Gaztambide-Fernández 2009; Walpole 2003). While 'academic language is no-one's mother tongue' (Bourdieu \& Passeron 1994: 8), it remains more accessible to those from middle-class backgrounds. Students from working class backgrounds, especially those who have not had a strong schooling experience, will have the toughest time at university and are the least likely to succeed.

Taking a literacies approach to looking at Higher Education means understanding that teaching is about enhancing epistemological access (Morrow 1993). The role of the educator is thus not only to transmit the knowledge in her possession, but to explicate the ways in which that knowledge is made, how it is deemed worthy by the discipline, and why it is articulated in the ways that it is. In this context, language is often considered 
as the conduit for transmitting academic knowledge, rather than being central to the individual's meaning making processes. However, in this article we argue that students' plurilingual realities and translanguaging practices are an overlooked resource in postgraduate writing practices.

Writing in the extracurricular spaces of interdisciplinary peer-led writing groups affords students the opportunity to interrogate the role of language as knowledge, and to critically shift their position to learning from accessing knowledge to knowing as a form of becoming. In this research article, we focus our attention on ways in which the use of home languages can enable processes of knowing as a form of becoming, or what Barnett terms 'epistemic becoming' (2009: 435). Our research posits that language biography writing that takes place in writing groups can function as a starting point for the experience of an 'extraordinary and intimate relationship between knowing and becoming' (p. 435). In this article, therefore, we aim to examine how writing groups can become part of curricula and pedagogies that are 'likely to elicit formation of the kinds of (epistemologically linked) dispositions and qualities' (p. 437) that could enable more rigorous academic engagement across disciplines and thereby broaden epistemological access as well as facilitate epistemological becoming, instead of sustaining and perpetuating learning practices that compartmentalise and exclude students' home languages (Banda 2000; Bangeni \& Kapp 2007; Makalela 2015; Makoe \& McKinney 2014; Maseko 2019).

As noted earlier, this article draws from the work of García and Otheguy (2019) in order to argue the necessity of moving away from the discourse of multilingualism, which advocates the use of home languages as language of tuition, to the concept of plurilingualism as repertoire and translanguaging as practice. It is important to activate this distinction in the context of South Africa, since, as Neville Alexander observes, 'even though Afrikaans and English are the languages of arithmetic minorities, they are the dominant languages and manifest all the features of what are generally referred to by sociolinguists and sociologists of language as 'majority' languages'. Conversely, Alexander continues, 'the demographically strong indigenous African languages, especially isXhosa and isiZulu, though, together, they are spoken as a first language by almost one-half of the population of South Africa and between $60 \%$ and $70 \%$ of all South Africans understand isiZulu manifest all the features of 'minority' languages in the typical West European country' (2001: 355-356). 
The choice of language and teaching in South Africa is amplified by the economic imperative to speak 'the dominant language (of power)' (Alexander 2005: 5)., p. ${ }^{4}$ Therefore, it is important to recognise the use of home languages as conscious choice and instrumental in facilitating epistemological access, rather than continuing the colonial situation in education where speakers find themselves limited to an ontology of 'being multilingual' while continuing to advantage English-knowing elites. ${ }^{5}$ This shift of perspective responds to the demands to decolonise Higher Education (Heleta 2016), away from a multilingualism where the knowledge of additional languages becomes an asset for European national citizens, and where multilingualism resides 'outside of their bodies, in the society' (García \& Otheguy 2019: 7). The reality of translanguaging in South Africa, however, suggests taking seriously the simultaneous use of languages in daily reality to speak about lived realities.

The language of teaching and learning is often reported as presenting an additional barrier in plurilingual students' experiences of exploring and developing academic literacy. In the context of current efforts to decolonise the curriculum, students need to be able to point out when disciplinary norms are reproduced that are nebulous and part of the hidden curriculum, instead of being explicitly elaborated on and critically reflected on, thus furthering a colonial matrix of language (Veronelli 2015) as embodied knowledge practice (Bhambra et al. 2018). For example, studies in South Africa have shown that when home languages are not used as the language of tuition and learning, students' performance is significantly poorer and their dropout rates higher (Mgqwashu 2011; Ngcobo 2014). By implication, teaching in ways that make the knowledge and related literacy practices explicit in a language that is

4 'The relevant essential proposition is simple enough. It states that in a multilingual society, it is in everyone's interest to learn the dominant language (of power), since this will help to provide equal opportunities in the labour market as well as in other markets. In post-colonial Africa, this has led to the almost complete marginalisation of the local languages of the people and the valorisation of English, French and Portuguese in the relevant African states'. (Alexander 2005: 5)

5 'My core proposition is that until and unless we are able to use the indigenous languages of South Africa, among other things, as languages of tuition at tertiary level, our educational system will continue to be skewed in favour of an English-knowing elite' (Alexander 2003: 22). 
accessible to students contributes to their success or, stated differently, their epistemological becoming. Unfortunately, such a mode of educational empowerment shall remain idealistic rather than actualisable for as long as English continues its role of gatekeeper of knowledge in the realm of Higher Education (Hurst 2016). This gatekeeper role persists despite studies that have shown that translanguaging practices through plurilingual inclusion of languages in Higher Learning can open up paths towards epistemic justice (Walker 2018).

It might be relevant to point out that this article is a research report and the result of the work of a group of transdisciplinary postgraduate scholars, whereas our main field of academic practice is outside of educational or curriculum studies. At the same time, we claim a space within the debate around Higher Education curricula, acknowledging that our work as writing group facilitators, through the process of self-reflexive, interdisciplinary group research has started processes of epistemological becoming in each of the research group members. Therefore, the argument presented here builds on both our practice as writing group facilitators, and the insight we gained throughout the process that writing practices draw from a traffic between practices of personal reflective and creative writing on the one hand and scholarly work as thinking on the other.

In this context, it is important to point out that plurilingual inclusion is a particular element in the decolonial turn that is currently being experienced in the academy (Bhambra et al. 2018). When knowledge and the related literacy practices are normalised, they become almost impervious to critique. By normalising the disciplinary norms of knowledge making, the academy protects it from the harsh light of deliberation. Teaching in ways that make practices explicit means that we have to be able to justify our expectations and this can assist us in seeing which norms are worthy of our stewardship and which need to be dismissed as part of an exclusionary legacy.

While epistemological access can be understood to comprise access to the content and practices of the target field, it should not be seen in isolation from epistemological becoming (Barnett 2009). Taking on a particular discipline or disciplines has implications for a student's sense of self. If we understand literacy practices as including the ways in which we think, talk, act, dress, walk and so on, then we understand that all of us have a repertoire of literacy practices that we can embody as the context demands. However, not all of these practices sit comfortably alongside each other. The number of 
testimonies about the alienating nature of the university in the 2015/2016 student protests (Badat 2016; Le Grange 2016) perhaps do not come as a surprise. If taking on the practices of the discipline entails taking on new ways of being and doing, the potential for identity issues to emerge is significant. If these practices are never opened to scrutiny and challenge, they can seem mysterious and even suffocating.

There are many ways in which the practices of the academy can enhance the likelihood of epistemological and ontological access in ways that are socially just. Many universities have created support programmes for students to improve their literacy practices, such as Academic Literacy or English as Additional Language courses. These interventions are however sometimes 'underpinned by a conceptualisation of students as being deficient' (Coleman 2016: 18) and often treat language practices as generic across the academy, rather than emerging from particular disciplines (Case et al. 2018). In addition, the writing practices taught tend to disregard the possibility of rigorous academic engagement that can happen when students are encouraged to tap into their translanguaging practices for meaning making. This, therefore, suggests that a South African Higher Education curriculum that embraces plurilingualism and translanguaging across disciplines (Ramani \& Joseph 2010), including writing groups and other additional programmes, could enable students to participate and contribute epistemologically, thereby activating their lived realities as knowledge rather than as obstacle.

\section{Tapping into Students' Plurilingual Repertoire through Translanguaging in Writing Groups}

Writing groups meet weekly at Rhodes University, where this study is situated, and serve to allow postgraduate scholars to experiment with various literacy practices, to help each other make them explicit and, at times, to support each other to challenge the dominance of particular practices, following Wilmot and McKenna (2018). This non-hierarchical space further offers students the opportunity to learn and share literacy practices between peers from different disciplines unhindered by constraints of grammar or formal language rules. Over the past years, the socio-political significance of knowledge production in South African Higher Education Institutions (HEIs) has been questioned more rigorously as Heleta (2016) reminds us. In this context, the writing group meetings provide students not only with 'inspiring and creative places where 
people talk, write and learn together because they are being nurtured, empowered and stimulated' (Aitchison 2009: 261), but also with safe spaces in which to develop their critical voice.

As stated earlier, the dominance of English as a medium of instruction has long been shown to constrain students' access to knowledge and disciplinary writing practices (Nomlomo \& Katiya 2018). There is also evidence to show that this has effects on students' self-worth and sense of identity since their home language seems to be deemed less valuable than the powerful medium of instruction (Castenell \& Pinar 1993; De Kadt \& Mathonsi 2003). Writing groups provide an opportunity for students to activate their plurilingual background through translanguaging as groups draw on their many languages in composing reflective pieces, pre-writing notes, short essays, and so on.

Students' plurilingual repertoire is an untapped opportunity to contribute significantly to the process of developing academic literacy. We understand academic literacy as praxis (Stierer 2008: 42) which builds on the home language spoken by the learner, thus activating the epistemic potential of translanguaging. This approach is supported by studies which show that tuition based on very late-exit transition (delay of transition from mother tongue as language of instruction to a different target language) or additive plurilingual education proves more effective in the achievement of academic literacy (Heugh 2011). In the South African context, multilingual and plurilingual practices are not acknowledged in language policies, thus continuing apartheid policies of separate languages which 'legitimise and give authority to standard English language at the expense of pluralism and diversity' (Makoe \& McKinney 2014: 670). In spite of the modernisation of South African languages from the turn of the century, ${ }^{6}$ the use of English language continues as a social marker of distinction, creating elitism and further associating African languages with inferiority (Mkhize \& NdimandeHlongwa 2014). In our writing groups, we set out to harness translanguaging as epistemological practice for the development of academic literacy practices,

${ }^{6}$ During the so called New African Movement (1900-1960) South African languages experienced a shift in meaning making through a vast range of print publications such as Imvo Zabantsundu (1884), Ilanga lase Natal (1903), Tsala ea Batho / Tsala ea Becauna (1910-915), or Umteteli wa Bantu (1920-1956) to mention a few. 
based on the assumption that plurilingual speakers have potentially broad access to disciplinary concepts. Accordingly, our writing groups provide the opportunity to address a significant question that is posed in this research article: How can a group of interdisciplinary postgraduate scholars perform, explore, and develop an understanding of translanguaging writing practices through self-reflexive language biography writing as educational practice for facilitating writing groups, so as to guide postgraduate students towards activating the potential of their social epistemological knowledge?

\section{Language Biographies as Participatory Methodology}

Here we outline the procedures undertaken for collecting and analysing the data discussed in this article. This research group is made up of five interdisciplinary writing facilitators coming from disciplines as unrelated as Chemistry, Environmental Science, Creative Writing, Psychology, Education, and Visual Art. As facilitators, we meet monthly to discuss how our groups are engaging and to share ideas about the development of literacy practices within the collegial ethos of the writing groups. To collect data and to fully grasp the implications of translanguaging practices for postgraduate scholarship, over the course of our monthly meetings, we wrote language biographies and reflective pieces and discussed how these could be activated in writing groups so as to enhance epistemological access and conceptual depth in academic writing. These language biographies were framed by the work of Busch and colleagues (2006), which outline how language biographies can open up opportunities for translanguaging in learning and to conscientise people (Freire 1974) about attitudes towards and practices of language.

Busch et al. (2006) posit that language biographies are more than just factual anecdotes and can be useful tools in classroom situations, giving learners a shared sense of perspective within a plurilingual environment. They are based on memory work, and, as acts of self-disclosure, require a safe writing space. In such settings, tensions between the dominant discourses and one's own (emerging) identity are openly addressed and revealed in a nonthreatening context. Thus, language biography writing also serves the political purpose of capturing the oral histories of decolonisation that might otherwise be absent from the classroom.

We used principles of Participatory Action Research (PAR) (FalsBorda \& Rahman 1991) to challenge and unpack the experiences of 
plurilingual postgraduate students in South African HEIs, on the basis of our own experiences as writing group facilitators. PAR is based on three aspects: participation in public life through reasoning about 'life in society and democracy'; actions grounded in collaborative inquiry as 'engagement with experience'; and research as 'soundness in thought' which draws from the practice of ordinary language (Chevalier \& Buckles 2013: 205 - 206). Critical pedagogy is based on collaborative thinking towards a shared concern so our research is, therefore, inspired by Barry Stierer's thoughts on critical pedagogy 'where theory and practice are integrated in order to effect action and change' (2008: 42).

Since group processes are conducive to research and experimentation, our work aimed at enabling each participant's active knowledge in the process. Thus, PAR is appropriate to this study that attempts to acknowledge the complexity and diversity of each of our plurilingual backgrounds and translanguaging practices, while at the same time enabling each of us to model this joint research process on writing in second languages in other contexts. To employ PAR also means to include the investigated in the process of investigation itself since this acknowledges that, given the proper tools, people who are affected by a problem not only better understand their realities, but will also be best equipped to address their struggles.

After writing language biographies we shared our pieces with each other and, apart from observing similarities and differences, we also further explored the memories in our language biographies. In this first phase of data analysis, the results were read and reread in our meetings. The narratives produced were then coded according to the dominant theme that was emerging in each narrative. The themes that emerged from the language biographies and reflective pieces include the following:

- Conceptual depth through translanguaging practices in plurilingualism;

- Affective processes: confusion/ exclusion/vulnerability;

- Conformity and resistance;

- Translanguaging as decolonisation (challenging and critiquing);

- Translanguaging a tool for epistemological access; and

- Identity validation.

After reflecting on our language biographies, we decided to write reflective pieces in which we contemplated which unexpressed premises became visible 
in both their form and content. This second phase of data collection was in line with the cyclic nature of PAR and was meant to explore silences and unconscious choices in our language biographies. Reading out our texts, we realised that we focused mainly on navigating between our home languages and English as language of instruction. Sharing our observations about this bias, we noticed that we did not realise the potential of all our languages as plurilingual speakers as intelligible choices in the process of reflection around the significance of 'language' in meaning making. In this process, a valuable finding was that we assumed that the field of reflection around 'language' in academia is unstructured, and that we took for granted that experimentation, creativity, and play in self-reflexive work would yield results which would mirror the role of each language that contributed to the process of our epistemological becoming. We therefore learned in this process that reflexive inputs on language biography writing is a relevant step in interrogating habitual academic writing constellations.

We framed this process of self-reflective discovery as 'memory work' ${ }^{7}$ The research group engaged in memory work by sharing mnemonic sound games used in childhood to remember the spelling of English words. This made evident that similar strategies exist across languages and created a sense of shared experience. Thus, as a plurilingual research group from different cultures and geo-political contexts, we were able to engage with affective processes in second language acquisition which are investigated by Mgqwashu (2009). A crucial difference between the language biographies and reflexive notes was the transition from factual narrative accounts about language acquisition and the emergent writing practices to narratives about the important scenes, figures, games, songs, and political events that have shaped their writing practises within what Rose (2004) has called the hidden curriculum (Rose 2004) as it continues in postgraduate studies.

7 This is a social constructionist and feminist research practice which is elaborated on in the South African contexts by scholars such as Pumla Gqola, Yvette Abrahams and Desiree Lewis and based on the work of Black Feminist scholars Audre Lorde and bell hooks. To do memory work means to reexamine what is remembered and to re-write one's past, as proposed by bell hooks who posits that Audre Lorde's 1982 novel Zami: A New Spelling of My Name could be seen as 'bio-mythography' (1989: 15). 
In the section that follows we analyse excerpts from the data. Each theme is discussed in relation to plurilingualism.

\section{Findings}

\subsection{Epistemological Depth through Translanguaging Practices}

The language biographies that research group members wrote presented different aspects of the role of translanguaging for epistemological access. While these practices differ from individual to individual, we found that some experiences were shared. We found that the following issues link epistemological access and translanguaging in the texts written by research group members.

Looking back at the experience of acquiring academic literacy, we reflected how working in English at first blocked out the use of concepts in home languages. However, after reviewing this question, we discussed the impact of having access to the same concept in different languages. In our discussion, some research team members claimed that keeping an awareness about the meaning of concepts in different languages in mind while writing would lead to confusion, while others maintained that it provides a deeper and broader approach towards concepts. In this regard, consider the following excerpt from the language biography of Facilitator Z:

I am currently doing my $\mathrm{PhD}$ and realising that I hardly ever engage my isiXhosa lens when engaging with concepts as a result it feels as though all my life I have been learning to forget concepts. Part of the decision to think in English is sparked by the illusion that it grants easier access to conceptualising about these concepts. However, there is something that happens within me when I tap into my home language that opens a whole new perspective and knowledge when I start thinking about for instance the concept of a 'mother' or 'possession' in isiXhosa. Therefore, I think something can be said about understanding and learning using one's home language.

There is no doubt that students working between different languages face a different situation than students whose home language is the same as the language of tuition. However, plurilingual students are used to navigating between languages although the contributions of the home language are at 
times avoided or not readily recognised. This narrative made clear that we need to discuss students' practices and needs when they learn in their second language.

Facilitator $\mathrm{W}$ reflects about a different awareness of language as medium in translanguaging practices - approaching mistakes differently when writing between languages. Often, sentences are formed according to the syntax of the home language. This would be revealed as a 'mistake' only when reading the full sentence in the target language. These experiences lead to different ways of engaging through the detour of writing in another language. One would revisit the text, reformulate, and move on. Another possibility, however, is to look again at the result of a direct (and incorrect) translation and to interrogate both, the text that is perceived as ungrammatical, as well as the underlying sentence which originates in the home language. What this could make visible are further underlying processes of language use, such as the use of metaphors and idioms. Facilitator $\mathrm{W}$ reflects on this process.

This struggle, however, also produces unintended sentence formations, sometimes I read what I did not mean to write. This way, the process of self-translation in writing does two things, not only thinking through what one thought by writing it down, but also with the interaction of the second language inserting new meaning in a sentence. Therefore, I stopped seeing this as struggle or waste of time, but rather as a way of thinking in two voices, one intended and one which runs between the lines of working in two languages.

The question raised here is how plurilingual speakers access complex expressions by 'throwing a metaphorical boomerang across languages' (Martin-Beltrán 2010: 266) through translanguaging. On the one hand, this process can potentially lead to a broader epistemological access, as observed by Facilitator W. On the other hand, the process of translanguaging makes visible instances in which metaphors or idioms need unpacking.

When working between different languages, plurilingual speakers often experience a reframing of habitualised forms of speech. These are gradually acquired in second language learning. The need to unpack opaque statements in translanguaging therefore lends itself to a more conscious use of idioms and metaphors, which need to be constructed into a translated form. As a result, we would argue that these processes should be raised when preparing 
writing group facilitators at South African HEIs, and that an ongoing awareness about them can help students to actualise their full potential as researchers and writers. While much research on collaborative learning and its effects on conceptual engagement has been conducted, not much research has been done on translanguaging as a tool for crossing conceptual thresholds. Analysis suggests that activating home languages in academic literacy practices can enable conceptual depth and threshold crossing (García \& Wei 2014).

\subsection{Conceptual Depth through Translanguaging Practices}

McKenna (2017) discusses the benefits of having collaborative spaces in postgraduate education to ensure that students achieve the required conceptual depth. Along with others (for example, ASSAf 2010; Cloete et al. 2015; McKenna (2017) raises concerns about the dominance of the individual Master-Apprentice supervision model that dominates postgraduate education in some disciplines. Writing groups provide a peer learning space in which students can engage in depth with others and thereby achieve conceptual threshold crossing.

Crossing a conceptual threshold is said to be transformative, irreversible, integrative, bounded, and troublesome (Meyer \& Land 2003). The process can be termed transformative because a new perspective is unlocked in the subject because of the learning. It is irreversible in that the subject cannot return to earlier simplistic understandings. The integrative element refers to making sense of new concepts in relation to previously accrued concepts and the characteristic of boundedness acknowledges that some concepts are discipline-specific, and that understanding is thus demarcated by the disciplinary lens through which one is looking (Meyer \& Land 2005). Furthermore, the crossing of conceptual thresholds can be considered troublesome in that this can challenge dominant forms of knowledge (McKenna 2017). We would argue that translanguaging can facilitate the crossing of conceptual thresholds, as is expressed by Facilitator W:

Two years ago, I experimented with spoken and written English in the MA programme in Creative Writing. I focussed on the bodily feeling of being in a third space, speaking a second language that is infused in complex processes of self-translation in creative writing, both as 
reflective process and as liberating practice. This experience brought about many new insights into my own attitudes and approaches towards my knowledge of language: I was forced to express myself more clearly not only because I wanted to avoid misunderstandings and tried to express myself in a language which I was not used to writ[ing] and speak[ing]. And since I started writing in English, I became aware of forms of German idioms and complex expressions which don't have a direct translation to other languages. As I was forced to unpack these, I learned to inspect concepts more critically than before, when I took the meaning of opaque expressions for granted.

Facilitator W reflects on the conceptualising blockages encountered in fixating on English proficiency in academic writing and the merits that could be gained through translanguaging and drawing on one's home language to supplement or challenge meaning. Upon reflection, the writing group facilitator recognises other ways of knowing which add nuance and critique to previously held conceptualisations of concepts through shifting between English and German. The shifts between the languages allowed the facilitator to achieve deeper engagement with core concepts and to achieve a conceptual depth that was not available had he shut off access to the understandings provided by his second language. The development of new language practices, however, is a difficult one as García and Wei (2014) point out, which amounts to learning a new way of languaging. Writing groups are spaces in which learners share their conscious effort in practicing new forms of thought since it is important to 'engage and interact socially and cognitively in the learning process in ways that produce and extend the students' languaging and meaning-making' (2014: 79).

\subsection{Conformity and Resistance}

Internationalisation of Higher Education has increased the necessity to embrace English as a lingua franca because of its linguistic hegemony. In a globalised world, there has been a growing appeal for the learning of English and while it affords disciplinary exchange in international spaces, there remains pressure to conform to the norms of a globally accepted language. This resistance to acknowledging and developing translanguaging may be understood as a response to the inferiority that is often ascribed to speakers' 
home languages, with the concomitant elevation of a foreign language to a level above theirs. It is believed that this imbalance often leads to the silencing of individual thoughts because of one's inability to express critical perspectives in the language deemed acceptable in such spaces. This is evidenced by Facilitator $\mathrm{V}$ who reflects on experiences of staying clear of translanguaging:

I always become hesitant to speak because I first think in my mothertongue then try to translate to English, spent several minutes thinking and reflecting if it makes sense to me. I have developed that fear of not knowing what people would think about my grammar and pronunciation of certain words. At the same time, what could have been a straight-to-the-point narration becomes a long and winding story as I would be trying to bring some important points on the table. This however tend to confuse some people who are not patient enough to grasp everything thereby causing me to react to this by silencing myself in certain discussions where I feel I would be judged.

A different aspect of this experience is shared by Facilitator Y who grew up in a plurilingual environment:

For me English became a language of communication alongside my home language ... Confusion often arises from this experience of having to negotiate two languages in two separate contexts, that of home and the public domain. Initially, it was difficult for me to comprehend both languages at the same time, but my management of them was made easier through the help of my mother who studied for a Bachelor of Arts degree in Linguistics. This provided her with the skills to teach in both languages, which was certainly of benefit to my own learning.

It is noteworthy that many of the language biographies and reflective pieces showed willingness to engage in the language of teaching and learning in most academic spaces (in our case, English) but the resistance to conform towards the academic norms still holds in a very subtle form. This is evidenced by Facilitator V's decision to silence herself to avoid self-expression through long complex narrations caused by translanguaging to conform to the group, even with valuable contributions to make. Facilitator $\mathrm{Y}$ reflects on learning to 
manage both languages and compartmentalising each according to the monolingual norm with the help of his mother. It is important to deliberate upon and discuss ways in which languages can be balanced rather than placing emphasis on one above the other. We argue, however, that more research needs to be done into how the practice of translanguaging can further original contributions to knowledge that draw from the rich epistemic realities of plurilingual speakers. Furthermore, writing groups can provide the space for inventing new ways of academic writing practices that comment on texts generated through translanguaging to generate a text that is intelligible in one of the used languages. These practices would result in students actively engaging in investigating how to make available meaning across curricula and languages ${ }^{8}$.

\subsection{Identity Validation}

Julie Menard-Warwick opens her 2005 interrogation of identity in the field of second language acquisition and literacy theory saying, 'As educational settings become more linguistically and culturally diverse, there has been a growing recognition that the multiple identities which students bring with them affect learning in powerful but unpredictable ways' (p. 253). The language biographic approach allowed us to take a different perspective through narratives and to compare experiences with the language biographies among different language groups. Thus, social and individual translanguaging practices of plurilingual contexts can be linked to varying concepts of social organisation, identity, and ethnicity (Busch et al. 2006). With the use of language biography and reflective pieces collected in this study, it was evident that language is an aspect of identity that is closely related to race, social class, occupation, education, and income. This can also influence language perceptions and prejudices. For example, Facilitator V indicated,

Being involved in an academic environment where I have to teach,

${ }^{8}$ García and Wei (2014: 60f) highlight the benefits of transgressing dual language structures, which allows students to reflect on their languages, correct each other and negotiate linguistic problems while making meaning, a process that results in 'more uptake from the learner, able to appropriate new language practices as their own'. 
give talks, and be involved in research completely changed my life. I cannot say I perfectly fit, but the fact that I have swallowed the fear of speaking English has drastically boosted my confidence in many ways. I can speak English without the fear of being judged and I believe I can even give tangible contributions during discussions.

The English language is used as the language of academic engagement in many institutions and one's academic capabilities are often evaluated according to the ability to write or speak in this one language only, which Facilitator $\mathrm{V}$ identifies in the study as stealing confidence from many whose first language is not English.

As I was growing up, I had to learn to adjust to both languages depending on the situation I would be in. I am proud of my understanding of English and my ability to use the language in an academic environment. However, I cannot run away from the fact that English being the only language of learning being used, it affects my confidence especially if I have to contribute in English.

In some instances, postgraduate students have reflected that the use of English as a language of communication and writing, especially if it is a second or third language, may influence the erosion of one's native identity and culture as one would prefer to be identified with English in order to fit in, as is recounted by Facilitator Z.

Learning English, the language of academic engagement in South Africa started at an early age and iqale ngokufuna ukufana nodade wethu (it all started with wanting to be like my sister) even though this language acquisition process would later progress independent of my sister.

As exemplified here, translanguaging makes available the simultaneous presence of concepts from various languages, activating meaning making through conceptualisation across languages as part of the process of speaking. The simultaneous use of 'udade/ sister' in one enunciation activates a conceptual depth that is rooted in social context as enabling epistemological processes (García \& Wei 2014). Rather than approaching the lexical items of 
'udade' and 'sister' as separate entries according to the normative use of separating languages, the glossary approach to 'translation' is removed and replaced by the embodied knowledge of sharing thought. The peer-led writing groups enable the appropriate social context for translanguaging, a space that is driven by the shared endeavour to create meaning, rather than by the desire to produce a normative outcome. This procedural activation of linguistic repertories has been conceptualised as 'heteroglossia' by Bakhtin (1981: 270), shifting the root of meaning making to the activity of speaking through 'language as communicative action'. ${ }^{2}$ Shifting the focus away from the 'dilemma filled' process of negotiating one's way towards producing thoughts in one 'target language', which is observed by Setati et al. (2002: 140), the speakers' languages cease to appear as separate entities, as the outcome of the normalized habitus of two monolinguals in one body (Grosjean 1989). The normalized stigma of hybrid languages or mixing languages activates the experience of lack and of not being good enough while writing across languages can open up further multimodal dimensions understanding. ${ }^{10}$ More often than not, plurilingual speakers experience their plurilingual practices according to the 'dominant discourse of 'separate bilingualism' . . . in which languages are viewed as discrete and bounded cultural entities attached to particular domains of use' (Preece 2016: 370). By making space for translanguaging, however, writing groups move the students' focus towards one speaking body, being perfectly capable of forming complex thought. We therefore argue that while the development of students' academic literacy is complex and is accompanied by contradictory processes of conformity, resistance, and identity validation, the simultaneous use of students' linguistic repertoire is essential for processes of what we would like to refer to epistemological becoming.

Thus, we argue that the curricula of Higher Education in South Africa need to provide spaces across disciplines that allow for translanguaging to activate students' vast linguistic-conceptual resources, rather than rushing towards the output of producing academic discourse using so-called perfect

${ }^{9}$ Creese and Blackledge (2011:1198) posit that this approach requires an 'explanation predicated on the fluidity and simultaneity of language use'.

${ }^{10}$ Taliaferro-Baszile (2019: 23) points toward the potential of 'reWriting in two languages or 'dialects' in one manuscript or even in one sentence; or with bold, fiery, righteous indignation that makes the page hot to the touch'. 
language. Writing groups as peer-led spaces based on the fundamental premise of collegiality can facilitate students' epistemological becoming where translanguaging is embraced as part of the students' conceptual growth. Examples of such spaces being activated in different ways in South African Universities are starting to emerge, like, for example, Dr Siphokazi Magadla's practice of Ukuzinza.

Furthermore, writing groups are social spaces in which South African students' plurilingual reality questions the ideology of the monolingual habitus in academia (Gogolin 1997; Yildiz 2012). Knowledge making in the academic community is based on discourse. Translanguaging confronts programmes of transformation of language policies with the realities of plurilingual scholars. In turn, members of the academic community are challenged to interrogate their assumed monolingual realities, disrupting raciolinguistic ideologies as Flores and Rosa (2015) note. Thus, writing groups can become spaces in which the move towards a new normal is refuted by interrogating language biographies across different lived experiences. Facilitator X's reflections around the linguistic background show that language biography writing can shift the reflection around the linguistic identity to another level.

My $\mathrm{PhD}$ required the reading of a collection of Afrikaans short stories which I experienced as easy to translate into English. In summary, I have a good understanding of Afrikaans but do not speak it.

I also consider myself to have two languages on the discursive level, or the level of register i.e. the language of analysis and the language of creative writing. I write journal articles, conference papers, peer reviews, literary reviews, poetry, short stories, and literary non-fiction.

In this context, writing groups offer space for growth in which students try out the literacy practices they have at their disposal, challenge the dominance of particular styles, genres, and tones, and engage playfully with the complex work of navigating knowledge production, literacy practices, and language development. The need for safe spaces for play is key because of the intricate identity work entailed. As stated above, our use of memory work was aimed at eliciting personal experiences which require intersectional framing of identities. Therefore, this discussion was not designed to provide simple truths, but is aimed, rather, at generating narratives that complicate plurilingual experiences in the contexts of South African Universities. 


\section{Conclusion}

In this article, we analysed our language biographies and reflective pieces as data so as to interrogate the significance of translanguaging processes in acquiring academic literacy, and to examine the role of writing groups as peerled spaces across curricula of different disciplines. In the course of coding the language biographies, we found that the writing processes were accompanied by complex affective processes, and that the writing of language biographies points to the difficulties associated with plurilingual students' experiences of developing their writing practices in the dominant language of instruction. Therefore, we argue that the connection between language of tuition and academic literacy skills needs to be reframed so as to change the prevalent normative monolingual of students' linguistic repertoires.

Students make sense of disciplinary norms in multiple ways and, while translanguaging may not be a useful resource for some, the complexities and contradictions implicit in a monolingual habitus of knowledge production consistently prove to disadvantage many others in South Africa given its response to massification. Dominant forms of knowledge production continue to alienate scholars while epistemological (in)access is continually linked to plurilingual students' inability to keep up with the curriculum or acquire the competencies required in postgraduate studies. We argue that a curriculum that is eager to transform should not only be emphatic about the possibilities of including plurilingual lived realities, but also acknowledge that they are indispensable in meaning making/ As Sembiante (2016: 57) points out, 'a critical language awareness and pedagogy may become indispensable for the field of curriculum and instruction as it searches for relevant perspectives in an increasingly diverse and globalized society'. Therefore, the cultivation of home language use in, for example, prewriting, essay writing, or chapter outlining could be on-the-ground sites in the curriculum for the activation of epistemological access, conceptual depth, conformity, and resistance and identity validation among plurilingual and monolingual scholars.

In conclusion, we claim that writing groups can become spaces in which students unlearn the separation of languages and practise new avenues towards acquiring academic literacy skills. The call to decolonise education around the globe (Bhambra et al. 2018) has placed a spotlight on plurilingual researchers who challenge the normalised knowledge inherent in the global discourse on multilingualism, exposing the historical monolingual bias that 
Guzula et al. (2016) point out, while drawing from their experience of translanguaging as a lived practice of knowledge. In the process of our research, we tried to refuse the tendency to read our data according to the theories that offer simplified answers. Instead, we embraced our research process as meaning making so as to understand that 'translanguaging is not simply a research method but rather part of a larger political struggle of linguistic self-determination for language-minoritized populations' and that 'translanguaging is a political act' (Flores 2014: n.p.). As a qualitative study, we engaged in a critical interrogation of the documents that we produced for this study and began to appreciate that these provide significant examples of the close connections between identity, language, and meaning making. Thus, we argue that the complex experiences by students who practice translanguaging need to find a place in curricular planning and that HEIs need to develop new approaches to make available spaces for these across the academy, within the formal curriculum and outside of it.

\section{References}

Academy of Science of South Africa (ASSAf) 2010. The PhD Study: An Evidence-based Study on how to Meet the Demands for High-level Skills in an Emerging Economy. Available at:

https://research.assaf.org.za/bitstream/handle/20.500.11911/34/2010_ass af_phd_study.pdf?sequence $=5$ \&isAllowed $=y$

Aitchison, C. 2009. Writing Groups for Doctoral Education. Studies in Higher Education 34, 8: 905-916.

https://doi.org/10.1080/03075070902785580

Alexander, N. 2001. Majority and Minority Languages in South Africa. In

Extra, G. \& D. Gorter (eds.): The Other Languages of Europe:

Demographic, Sociolinguistic and Educational Perspectives. Sydney:

Multilingual Matters Ltd.

Alexander, N. 2003. The African Renaissance and the Use of African Languages in Tertiary Education (PRAESA Occasional Papers No. 2). Cape Town: Project for the Study of Alternative Education in South Africa.

Alexander, N. 2005. Language, Class and Power in Post-apartheid South Africa. Harold Wolpe Memorial Trust Open Dialogue Event, 27 October 
Fouad Asfour, et al.

2005, Iziko Museum, Cape Town.

Badat, S. 2016. Deciphering the Meanings and Explaining the South African

Higher Education Student Protests of 2015-16. Pax Academica 1: 71106.

Bakhtin, M.M. 1981. The Dialogic Imagination: Four Essays by M.M. Bakhtin. Emerson, C. \& M. Holquist (trans.). Austin: University of Texas Press.

Banda, F. 2000. The Dilemma of the Mother Tongue: Prospects for Bilingual Education in South Africa. Language, Culture and Curriculum 13, 1: 5166, https://doi.org/10.1080/07908310008666589

Bangeni, B. \& R. Kapp 2007. Shifting Language Attitudes in Linguistically

Diverse Learning Environment in South Africa. Journal of Multilingual and Multicultural Development 28, 4: 253-269.

https://doi.org/10.2167/jmmd495.0

Barnett, R. 2009. Knowing and Becoming in the Higher Education Curriculum.

Studies in Higher Education 34, 4: 429-440.

https://doi.org/10.1080/03075070902771978

Bhambra, G.K. 2018. Decolonising the University. London: Pluto Press.

Bourdieu, P., J-C Passeron \& M. Saint Martin (eds.). 1994. Introduction:

Language and Relationship to Language in the Teaching Situation. In

Bourdieu, P., J.C. Passeron, \& M. Saint Martin (eds.): Academic

Discourse: Linguistic Misunderstanding and Professorial Power.

Stanford: Stanford University Press.

Busch, B., A. Jardine, \& A. Tjoutuku 2006. Language Biographies for Multilingual Learning. PRAESA Occasional Articles 24.

Case, J.M., D. Marshall, S. McKenna, \& D. Mogashana. 2018. Going to

University: The Influence of Higher Education on the Lives of Young

South Africans. Volume 3. Cape Town: African Minds.

https://doi.org/10.47622/9781928331698

Castenell, L.A. \& W.F. Pinar 1993. Understanding Curriculum as Racial Text:

Representations of Identity and Difference in Education. New York: SUNY Press.

Chevalier, J.M. \& D.J. Buckles 2013. Participatory Action Research: Theory and Methods for Engaged Inquiry. New York: Routledge.

https://doi.org/10.4324/9780203107386

Cloete, N., J.M. Mouton, \& C. Sheppard 2015. The Doctorate in South Africa:

Discourse, Data and Policies. Cape Town: African Minds. 
https://doi.org/10.47622/9781928331001

Coleman, L. 2016. Offsetting Deficit Conceptualisations: Methodological

Considerations for Higher Education Research. Critical Studies in

Teaching and Learning 4, 1: 16-38.

https://doi.org/10.14426/cristal.v4i1.59

Creese, A. \& A. Blackledge 2011. Separate and Flexible Bilingualism in

Complementary Schools: Multiple Language Practices in Interrelationship. Journal of Pragmatics 43, 1196-1208.

https://doi.org/10.1016/j.pragma.2010.10.006

De Kadt, E., \& N. Mathonsi 2003. Writing in English with an 'African Voice':

Ownership, Identity and Learning. Journal for Language Teaching= Ijenali Yekufundzisa Lulwimi= Tydskrif vir Taalonderrig 37, 1: 92-103. https://doi.org/10.4314/jlt.v37i1.5982

Fals-Borda, O. \& M.A. Rahman 1991. Action and Knowledge. New York: Apex Press. https://doi.org/10.3362/9781780444239

Flores, N. 2014. Let's Not Forget that Translanguaging is a Political Act.

Available at: https://educationallinguist.wordpress.com/2014/07/19/letsnot-forget-that-translanguaging-is-a-political-act

(Accessed on 5 May 2020).

Flores, N. \& J. Rosa 2015. Undoing Appropriateness: Raciolinguistic Ideologies and Language Diversity in Education. Harvard Educational Review 85: 149-171. https://doi.org/10.17763/0017-8055.85.2.149

Freire, P. 1974. Conscientisation. CrossCurrents 24,1: 23-31.

García, O. \& R. Otheguy 2019. Plurilingualism and Translanguaging:

Commonalities and Divergences. International Journal of Bilingual Education and Bilingualism.

https://doi.org/10.1080/13670050.2019.1598932

García, O., \& L. Wei 2014. Translanguaging: Language, Bilingualism and Education. London: Palgrave Macmillan.

https://doi.org/10.1057/9781137385765 4

Gaztambide-Fernández, R. 2009. The Best of the Best. Cambridge: Harvard University Press. https://doi.org/10.2307/j.ctvinrv46

Gogolin, I. 1997. The 'Monolingual Habitus' as the Common Feature in

Teaching in the Language of the Majority in Different Countries. Per

Linguam 13, 2. https://doi.org/10.5785/13-2-187

Grosjean, F. 1989. Neurolinguists, Beware! The Bilingual is not Two Monolinguals in one Person. Brain and Language 36, 1: 3-15. 
Fouad Asfour, et al.

https://doi.org/10.1016/0093-934X(89)90048-5

Guzula, X., C. McKinney \& R. Tyler 2016. Languaging-for-learning:

Legitimising Translanguaging and Enabling Multimodal Practices in

Third Spaces. Southern African Linguistics and Applied Language

Studies, 34, 3: 211-226.

https://doi.org/10.2989/16073614.2016.1250360

Heleta, S. 2016. Decolonisation of Higher Education: Dismantling Epistemic

Violence and Eurocentrism in South Africa. Transformation in Higher

Education 1, 1: a9.

https://doi.org/10.4102/the.v1i1.9

hooks, b. 1989. Talking Back: Thinking Feminist, Thinking Black. Boston:

South End Press.

Heugh, K. 2011. Theory and Practice - Language Education Models in Africa:

Research, Design, Decision-Making and Outcomes. In Ouane, A. \& C.

Glanz (eds.): Optimising Learning, Education and Publishing in Africa:

The Language Factor. Hamburg: UNESCO Institute for Lifelong

Learning, 105-156. Available at:

https://files.eric.ed.gov/fulltext/ED540491.pdf

(Accessed 2 May 2020).

Hurst, E. 2016. Navigating Language: Strategies, Transitions, and the

'Colonial Wound' in South African Education, Language and Education

30, 3: 219-234. https://doi.org/10.1080/09500782.2015.1102274

Khan, S. \& F. Asfour 2018. Whitespeak: How Race Works in South African Art Criticism Texts to Maintain the Arts as the Property of Whiteness. In Kraehe, A.M., R. Gaztambide-Fernández \& B.S. Carpenter II (eds.): The Palgrave Handbook of Race and the Arts in Education. Cham: Palgrave Macmillan. https://doi.org/10.1007/978-3-319-65256-6_11

PMCid:PMC6056674

Le Grange, L. 2016. Decolonising the University Curriculum. South African Journal of Higher Education 30, 2: 1-12. https://doi.org/10.20853/30-2$\underline{709}$

Magadla, S. 2018. Tragicomic Hope, Nokuzinza as Black Matriarchal Inheritance. Vice-Chancellor's 2018 Teaching Award Lecture, Rhodes University, Makhanda, 28 February. In Engel, K. International Relations from an African Perspective. Available at:

https://www.ru.ac.za/latestnews/internationalrelationsfromanafricanpers pective.html (Accessed 2 May 2020). 
Makalela, L. 2015. Translanguaging as a Vehicle for Epistemic Access: Cases for Reading Comprehension and Multilingual Interactions. Per Linguam: A Journal of Language Learning = Per Linguam: Tydskrif vir Taalaanleer 31, 1: 15-29.

https://doi.org/10.5785/31-1-628

Makoe, P. \& C. McKinney 2014. Linguistic Ideologies in Multilingual South African Suburban Schools, Journal of Multilingual and Multicultural Development 35, 7: 658-673.

https://doi.org/10.1080/01434632.2014.908889

Martin-Beltrán, M. 2010. The Two-way Language Bridge: Co-constructing Bilingual Language Learning Opportunities. The Modern Language Journal 94, 2: 254-277.

https://doi.org/10.1111/j.1540-4781.2010.01020.x

Maseko, P.B. 2019. A Transformative Exploration of Epistemic Individual(istic) Identity Formation within a Synergistic Decolonial Student Support System. Perspectives in Education 36, 2: 15-27. Available at: https://doi.org/10.18820/2519593X/pie.v36i2.3

(Accessed on 5 May 2020).

McKenna, S. 2010. Cracking the Code of Academic Literacy: An Ideological Task. In Hutchings, C. \& J. Garraway (eds.): Beyond the University Gates: Provision of Extended Curriculum Programmes in South Africa. Makhanda: Rhodes University.

McKenna, S. 2017. Crossing Conceptual Thresholds in Doctoral Communities. Innovations in Education and Teaching International 54, 5: 458-466. https://doi.org/10.1080/14703297.2016.1155471

Menard-Warwick, J. 2005. Both a Fiction and an Existential Fact: Theorizing Identity in Second Language Acquisition and Literacy Studies. Linguistics and Education 16, 253-274.

https://doi.org/10.1016/j.linged.2006.02.001

Meyer, J.H. \& R. Land 2005. Threshold Concepts and Troublesome Knowledge (2): Epistemological Considerations and a Conceptual Framework for Teaching and Learning. Higher Education 49, 3: 373388. https://doi.org/10.1007/s10734-004-6779-5

Meyer, J.H.F., \& R. Land 2003. Threshold Concepts and Troublesome Knowledge: Linkages to Ways of Thinking and Practising within the Disciplines. In Rust, C. (ed.): Improving Student Learning. Theory and Practice - 10 Years on. Oxford: OCSLD. 
Fouad Asfour, et al.

Mgqwashu, E. 2009. On Becoming Literate in English: A During- and Postapartheid Personal Story. Language Learning Journal 37, 3: 293-303. https://doi.org/10.1080/09571730903208447

Mgqwashu, E. 2011. Academic Literacy in the Mother Tongue: A Pre-requisite for Epistemological Access. Alternation 18, 2: 159-178.

Mkhize, N. \& H. Ndimande-Hlongwa 2014. African Languages, Indigenous Knowledge Systems (IKS), and the Transformation of the Humanities and Social Sciences in Higher Education. Alternation 21, 2: 10-37.

Morrow, W. 1993. Epistemological Access in the University. Academic Development Issues 1, 1: 3-5.

Ngcobo, S. 2014. Dual Language Instruction: Its Impact on Attitudes Towards the Role of African Languages in Education. In Hibbert, L. \& C. van der Walt (eds.): Multilingual Universities in South Africa. Reflecting Society in Higher Education. Bristol: Multilingual Matters.

https://doi.org/10.21832/9781783091669-010

Nomlomo, V. \& M. Katiya 2018. Multilingualism and (Bi)literacy Development for Epistemological Access: Exploring Students Experience in the Use of Multilingual Glossaries at a South African University. Educational Research for Social Change 7, 1: 77-93.

https://doi.org/10.17159/2221-4070/2018/v7i1a6

Oluwole, D., P. Mason, G. Achadu, P. Mataruse, F. Asfour, S. McKenna \& G.

Chakona 2018. Writing Together to Write Better Alone: Postgraduate Writing Groups as Spaces of Agency Development. South African Journal of Higher Education 32, 8: 370-381.

https://doi.org/10.20853/32-6-2963

Preece, S. 2016. An Identity Transformation? In Preece S. (ed.): The Routledge Handbook of Language and Identity. New York: Routledge.

Ramani, E. \& M. Joseph 2010. Promoting Academic Competence in Two Languages: A Case Study of a Bilingual BA Degree (in English and Sesotho sa Leboa) at the University of Limpopo. EFL Journal 1, 2: 33-59.

Rosa, J. \& N. Flores 2017. Unsettling Race and Language: Toward a Raciolinguistic Perspective. Language in Society 46, 5: 621-647. https://doi.org/10.1017/S0047404517000562

Rose, D. 2004. Sequencing and Pacing of the Hidden Curriculum: How Indigenous Learners are Left Out of the Chain. In Muller, J., B. Davies \& A. Morais (eds.): Reading Bernstein, Researching Bernstein. New York: Routledge. 
Sembiante, S. 2016. Translanguaging and the Multilingual Turn: Epistemological Reconceptualization in the Fields of Language and Implications for Reframing Language in Curriculum Studies. Curriculum Inquiry 46, 1: 45-61.

https://doi.org/10.1080/03626784.2015.1133221

Setati, M., J. Adler, Y. Reed \& A. Bapoo 2002. Incomplete Journeys: Codeswitching and Other Language Practices in Mathematics, Science and English Language Classrooms in South Africa. Language and Education 16, 2: 128-149. https://doi.org/10.1080/09500780208666824

Shabanza, K.J. 2017. Enhancing Reflection on Writing. In Clarence, S. (ed.): Writing Centres in Higher Education. Stellenbosch: African Sun Media.

Stierer, B. 2008. Learning to Write about Teaching: Understanding the Writing Demands of Lecturer Development Programmes in Higher Education. In Murray, R. (ed.): The Scholarship of Teaching and Learning in Higher Education. Maidenhead: Open University Press.

Taliaferro-Baszile, D.T. 2019. Rewriting/ Recurricularlizing as a Matter of Life and Death: The Coloniality of Academic Writing and the Challenge of Black Mattering therein, Curriculum Inquiry 49, 1: 7-24.

https://doi.org/10.1080/03626784.2018.1546100

Veronelli, G.A. 2015. The Coloniality of Language: Race, Expressivity,

Power, and the Darker Side of Modernity. Wagadu: A Journal of

Transnational Women's \& Gender Studies 13, 108-134.

wa Thiong'o, N. 1987/ 1994. Decolonising the Mind. The Politics of Language in African Literature. Harare: Zimbabwe Publishing House.

Walker, M. 2020. Failures and Possibilities of Epistemic Justice, with some Implications for Higher Education. Critical Studies in Education 61, 3: 116. https://doi.org/10.1080/17508487.2018.1474774

Walpole, M. 2003. Socioeconomic Status and College: How SES Affects College Experiences and Outcomes. The Review of Higher Education 27, 1: 45-73. https://doi.org/10.1353/rhe.2003.0044

Wilmot, K. \& S. McKenna 2018. Writing Groups as Transformative Spaces. Higher Education Research \& Development 37, 4: 868-882. https://doi.org/10.1080/07294360.2018.1450361

Yildiz, Y. 2012. Beyond the Mother Tongue: The Postmonolingual Condition.

New York: Fordham University Press.

https://doi.org/10.2307/j.ctt13x0cqr 
Fouad Asfour, et al.

Fouad Asfour

Visiting researcher

Wits School of Arts

University of the Witwatersrand

Johannesburg

fouad.asfour@gmx.net

Yanela Ndabula

Researcher

Critical Studies in Sexualities and Reproduction Research Programme

Rhodes University

Makhanda (Grahamstown)

y.ndabula@ru.ac.za

Gamuchirai Chakona

Research Assistant at the Environmental Learning Research Centre (ELRC)

Department of Education

Rhodes University

Makhanda (Grahamstown)

G.Chakona@ru.ac.za

Paul Mason

Research Associate

Department of Literary Studies in English

Rhodes University

Makhanda (Grahamstown)

pm6308@gmail.com

David O. Oluwole Postdoctoral Fellow

1 Center for Postgraduate Studies

Rhodes University

Makhanda (Grahamstown)

2 Department of Chemistry

Cape Peninsula University of Technology

Cape Town

davido.oluwole@gmail.com 